\title{
Qualitative and quantitative assessment of degeneration of cervical intervertebral discs and facet joints
}

\author{
Joris Walraevens · Baoge Liu · Joke Meersschaert • \\ Philippe Demaerel · Hans Delye $\cdot$ Bart Depreitere · \\ Jos Vander Sloten · Jan Goffin
}

Published online: 27 January 2009

(C) Springer-Verlag 2009

\section{Erratum to: Eur Spine J}

\section{DOI 10.1007/s00586-008-0820-9}

Four authors are currently lacking from the author list.

The missing authors are:

\section{Joke Meersschaert}

Division of Radiology,

KULeuven, University Hospital Gasthuisberg,

Leuven, Belgium

\section{Philippe Demaerel}

Division of Radiology,

KULeuven, University Hospital Gasthuisberg,

Leuven, Belgium

\section{Hans Delye}

Division of Experimental Neurosurgery and Neuroanatomy, KULeuven, University Hospital Gasthuisberg, Leuven, Belgium

\section{Bart Depreitere}

Division of Experimental Neurosurgery and Neuroanatomy, KULeuven, University Hospital Gasthuisberg, Leuven, Belgium

The online version of the original article can be found under doi:10.1007/s00586-008-0820-9.

J. Walraevens $(\bowtie) \cdot J$. Vander Sloten

Division of Biomechanics and Engineering Design,

KULeuven, Celestijnenlaan C300, 3001 Heverlee, Belgium

e-mail: joris.walraevens@mech.kuleuven.be

B. Liu $\cdot$ H. Delye $\cdot$ B. Depreitere $\cdot$ J. Goffin

Division of Experimental Neurosurgery and Neuroanatomy,

KULeuven, University Hospital Gasthuisberg, Leuven, Belgium

J. Meersschaert · P. Demaerel

Division of Radiology, KULeuven,

University Hospital Gasthuisberg, Leuven, Belgium 